\title{
Evaluation of Antiulcer Activity of Laghusoothshekhar (an Ayurvedic Formula) in Pyloric Ligature Induced Gastric Ulcers in Albino Rats
}

\author{
Nilofer Sayed*, Vandana Barve \\ Department of Pharmaceutical Sciences, P.R.E.S College of Pharmacy, Nashik, Maharashtra, India \\ Student:syeda_g@rediffmail.com* \\ Mentor:vandanabarve26@gmail.com
}

\begin{abstract}
Laghusoothshekhar is an ayurvedic formula widely used for gastritis and peptic ulcers that has been described in various ayurvedic texts such as Bharat Bhaishajya Ratnakar, Ayurved saar sangraha and Nav sambita with slight variations in their ingredients. Marketed formulas from the first two references are available but the study of this formula from nav sambita is not yet carried out nor is it available commercially. It is a simple formula of few ingredients and is widely prepared and used by ayurvedic practitioners for treating gastritis (both acute and chronic) and peptic ulcers. Hence, efforts were taken to evaluate its antiulcer activity. Four groups comprising of six animals each were studied. Control Group: vehicle ( $2 \% \mathrm{w} / \mathrm{v}$ gum acacia), Group A: $(50 \mathrm{mg} / \mathrm{kg})$, Group B: (100 mg/kg), Group C: ranitidine (25 mg/kg). One hour after the last dose, pyloric ligation was done and animals were deprived of food and water for 4 hours, thereafter sacrificed and the number of ulcers and their severity was calculated. Both the doses of Laghusoothshekhar showed significant anti-ulcer activity and the histopathological findings of the gastric tissues confirmed the same. The results proved that the drug is as efficient as the standard drug ranitidine used in the treatment of gastritis and peptic ulcers. Ranitidine inhibits acid production by reversibly blocking $\mathrm{H}_{2}$ receptors on the basolateral membrane of parietal cells in the stomach.
\end{abstract}

\section{KEYWORDS}

Laghusoothshekhar; Pyloric Ligation; Ranitidine; Nav Sambita; Ayurveda; Amlapitta; Peptic Ulcers; Gastritis; Naagvel Patra; Ginger; Suvarna Gairik

\section{INTRODUCTION}

Gastritis is simply defined as inflammation of the stomach lining; it may be acute or chronic in nature leading to formation of peptic ulcers. With the present lifestyle changes, improper working conditions, improper eating habits, smoking, alcohol, emotional stress, over consumption of caffeine, over consumption and long term use of aspirin and other non-steroidal antiinflammatory drugs (NSAIDs), Helicobacter pylori infection; all these reasons have made gastritis as common as cold or flu. The current medicinal treatment of gastritis and gastritis induced peptic ulcer is generally based on triple therapy regimen inhibition of gastric acid secretion by histamine $\mathrm{H}_{2}$ antagonists, Proton pump inhibitors as well as mucosal protective therapy provided by sucralfate and bismuth along with use of antibiotics for $H$. pylori. These therapies are costly along with its numerous side effects such as a headache, bowel upset, dry mouth, rashes, elevation of liver enzymes seen in $\mathrm{H}_{2}$ antagonists and achlorhydria and hypergastrinemia seen due to prolonged use of proton pump inhibitors. ${ }^{1}$ The problem of antibiotic resistance in the treatment of $H$. pylori infection is also a major concern these days. Hence need arises for safer and efficient drugs which are easy to manufacture and cost effective. Hence, herbal and herbo-mineral formulas stand a good alternative in the present scenario.

Laghusoothshekhar a well-known formula for pitta dosh and amlapitta, ${ }^{2}$ which can be correlated with gastritis has been described in many ayurvedic texts such as Bharat Bhaishajya Ratnakar, Ayurved Saar Sangraha and Nav Sambita with slight variations in their ingredients of these the former two are manufactured and marketed by pharmaceutical companies but no marketed samples are available from the reference mentioned in Nav Sambita even though it is simple to prepare and widely used by Ayurvedic practitioners. Hence, the present study is undertaken to evaluate the efficacy of this formula with regards to its anti-ulcer activity.

This formula consists of three major ingredients, dry ginger powder; fresh juice of betel leaves (Piper betle) called Naagvel patra in Sanskrit and purified yellow ochre called suvarna gairik in Sanskrit. It has been reported that ginger has shown its efficacy in gastritis and peptic ulcer in many ways. It has found to have in vitro activity against H. Pylori, ${ }^{3}$ a potent inhibitor of protonpotassium ATPase activity, ${ }^{4}$ thus proves to have a multi-step approach in treating gastritis and peptic ulcers. It also enhances gastric emptying. ${ }^{5}$ 
It also has anti 5-HT inhibitor activity, ${ }^{6,7}$ thus proving to have a good antiemetic activity which helps in alleviating one of the major symptoms of gastritis. ${ }^{8}$ In a recent study done on betel leaves, it was seen that its hot water extract increased the mucus content adhering to the wall of gastric mucosa thereby having a gastro protective action over the gastric mucosal layer. It also possesses anti-ulcer activity by inhibiting free radical induced chain reaction in the process of ulcer formation. ${ }^{9}$ Yellow ochre, an oxide of iron, is known to be effective against various bleeding disorders, vomiting, disorders due to poison ingestion, antiemetic activity, burning sensation and diseases of the abdomen. ${ }^{10}$ Hence, the anti-ulcer activity of Laghusoothshekhar which is a combination of the above mentioned ingredients was studied in pyloric ligature induced gastric ulcers in albino rats.

\section{MATERIALS AND METHODS}

\section{Procurement of test drugs}

Laghusoothshekhar as per Nav Sambita indicates the presence of three components, dried ginger powder, purified yellow ochre and fresh betel leaves. Dried ginger powder and yellow ochre was provided by the in-house dispensing stores of Ayurved Mahavidyalaya and Fresh betel leaves were taken from the botanical garden of Ayurved Mahavidyalaya, Sion which was authenticated by Dr. Sudha Asthana, MSc, Ph.D. (Botany), Department of Botany at S.I.E.S College of Arts, Science and Commerce, Sion.

\section{Formulation of the drug}

The drug was formulated at Sion Ayurved Mahavidyalaya as per the procedure mentioned in the ayurvedic text Nav Sambita with certain modifications done as per the present requirements. Yellow ochre and ginger powder was sterilized in hot air over at $160^{\circ} \mathrm{C}$ for two hours. Yellow ochre was purified by mixing and grinding it in cow's milk using the mortar and pestle till it acquired a paste like consistency, then the mixture was placed in the refrigerator at $4^{\circ} \mathrm{C}$ for drying. Cow's milk was again added to the dried mixture and ground, this cycle was repeated thrice. Next day equal quantities of this dried purified yellow ochre and ginger powder was taken and soaked in fresh juice of betel leaves. This mixture was mixed and ground till it acquired a pasty consistency. The mixture was then placed in a refrigerator and kept overnight, next day the dried mixture was again submerged in the juice of fresh betel leaves and ground, this procedure was repeated five times. The process of mixing and grinding solid particles with a liquid component is called Bhavana in Ayurveda. The amount of liquid component should be sufficient enough to submerge all the powder ingredients. ${ }^{11}$ The dried powder was then suspended in purified water using $2 \%$ gum acacia as suspending agent thus making it convenient to administer the formula to the experimental rodents.

\section{Experimental site}

The antiulcer study carried out at Pharmacology laboratory of P.R.E.S College of Pharmacy, Chincholi, Nashik. The experiments were performed after approval from institutional animal ethics committee CPCSEA Registration No: 1345/a/10/CPCSEA.

\section{Experimental Animals}

Sprague Dawley rats (200-250 g) were used for the present study. Each rat was placed in a separate cage with wide mesh wire bottoms to prevent coprophagia during the experiment. They were maintained under standard environmental conditions (temperature $23 \pm 2^{\circ} \mathrm{C}$, relative humidity $55 \pm 10 \%$ and 12 hours light dark cycle) and were fed with standard pellet diet and water ad libitum. ${ }^{12,13}$

\section{Dose Fixation}

The human dose of Laghusoothshekhar is $500 \mathrm{mg}-1000 \mathrm{mg} /$ day. The dose for the experimental study was calculated by converting the human dose to animal dose based on the body surface area ratio using the table of Paget and Barnes. ${ }^{14}$ i.e. [Adult dose $\times 0.018] \times 5$.

Animal grouping

Thus, 24 rats were kept in four groups comprising of six animals each.

Control: Received vehicle i.e. $2 \% \mathrm{w} / \mathrm{v}$ gum acacia for a period of 5 days twice a day

Group A: Received the drug in dose $50 \mathrm{mg} / \mathrm{kg}$ twice a day for a period of 5 days

Group B: Received the drug in dose $100 \mathrm{mg} / \mathrm{kg}$ twice a day for a period of 5 days

Group C: Received Ranitidine (standard drug) $25 \mathrm{mg} / \mathrm{kg}$ twice a day for period of 5 days

Gastric ulcer induction in the rats

Shay's pyloric technique was used to induce gastric ulcers in rats. The drug (Laghusoothshekhar) and ranitidine were suspended in the vehicle and after 24 hours of fasting the drug was administered via the oral route twice a day for five days. One hour after the last dose, pyloric ligation was done in all the rats under general anesthesia (ether) and the animals were deprived of food and water for four hours. ${ }^{15}$

After four hours all rats were sacrificed using cervical dislocation technique. Stomach was removed after tying the lower oesophageal end and the pyloric end of the stomach. Then the stomach was incised along the greater curvature and rinsed 
with $2 \mathrm{~mL}$ distilled water. After rinsing, the entire stomach was stretched on a frog board and with the help of magnifying glass the number and degree of ulceration were noted and the ulcer index, $\%$ protection was calculated. Ulcers were mostly seen near the pyloric end and the lower part of gastric fundus. The entire stomach was then placed in bottles containing $10 \%$ formalin and sent to the histopathology department, where the sections were taken mainly from the lower portion of the gastric fundus and the pyloric end of the stomach, slides were prepared and the reporting was done at the pathology department of Holy Family Hospital, Bandra.

Assessment of stomach ulcer

The severity of ulcer and the total number of ulcer in each rat was recorded for calculating ulcer index. Ulcer index was calculated as follows: ${ }^{16}$

0-No visible ulcer

0.5-Red colouration

1-Superficial ulcers

1.5-Haemorrhagic streak

2-Deep ulcers

3-Perforation of gastric wall

Calculation of ulcer index:

$$
\mathbf{U I}=\mathbf{U N}+\mathbf{U S}+\mathbf{U P} \times 10^{-1}
$$

where $\quad$ UI $=$ Ulcer index

$$
\begin{aligned}
& \mathrm{UN}=\text { Average of number of ulcer per animal } \\
& \mathrm{US}=\text { Average of severity score } \\
& \mathrm{UP}=\text { Percentage of animal with ulcer }
\end{aligned}
$$

and percentage protection was calculated by using the formula:

\section{$\%$ Protection $=\underline{\text { Ulcer Index }(\text { control })-\text { Ulcer Index (test) }}$ Ulcer Index (control)}

Histopathological Studies

For the histopathological study, the incised stomach was washed with distilled water and placed in 10\% formalin solution prior to dehydrating, wax embedding, sections were taken mainly from the lower portion of gastric fundus and the pyloric end of the stomach, staining was done with haematoxylin and eosin. Histological evaluation of the gastric damage was done using light microscopy under 10x and 50x magnifications.

\section{RESULTS AND DISCUSSIONS}

Gastritis is inflammation of the stomach lining which at a chronic stage leads to the formation of peptic ulcers. Laghusoothshekhar, the formula taken from nav samhita is widely used by many Ayurveda practitioners but no documented evidence is available, hence, this study was carried out. Pyloric ligature method was used to induce ulcers in the rats. Pyloric ligation causes accumulation of gastric juice and hindrance of gastric blood circulation which leads to damage of gastric tissue lining and ulcer formation. It was found that pyloric ligation produced expected lesions in the control group and in animals of pre-treated groups ulcer score was significantly reduced. The percentage protection and ulcer index of animals in group B which received $100 \mathrm{mg} / \mathrm{kg} /$ day of the drug Laghusoothshekhar showed effects similar to ranitidine which is a standard drug used in the treatment of gastritis. The histopathology studies also supported the results. It has been reported that each of the ingredients used in this formula individually helps in the treatment of gastritis. ${ }^{3-10}$ Hence it can be concluded that the antiulcer activity of Laghusoothshekhar is a synergistic action of all the ingredients; moreover, the unique method of its preparation plays an important role in enhancing its activity. Yellow ochre is chemically $\mathrm{Fe}_{2} \mathrm{O}_{3}$. Iron is a transition element; these elements are known for its good adsorption properties and tendency to form interstitial compounds. Small atoms of non-metallic elements such as carbon, hydrogen, nitrogen get trapped in the vacant spaces of lattices of the transition metal atoms. ${ }^{18}$ Thus, during the process of mixing and grinding yellow ochre with the juice of betel leaves, there is every possibility that the active components of the juice interacts with iron leading to a more stable and effective combination of these ingredients. Although 
more research needs to be done to ascertain the interactions between various ingredients that take place during the preparation of an Ayurveda formula. During the entire period that the drug was administered animals did not show any toxic signs such as weight loss or loss of hair. Detailed study can be conducted related to its toxicity. Other parameters, such as the mucus content and $\mathrm{pH}$, can be evaluated which will provide more complete information of Laghusoothshekhar.

\section{Control: Vebicle $(2 \% \mathrm{w} / \mathrm{v}$ gum acacia)}
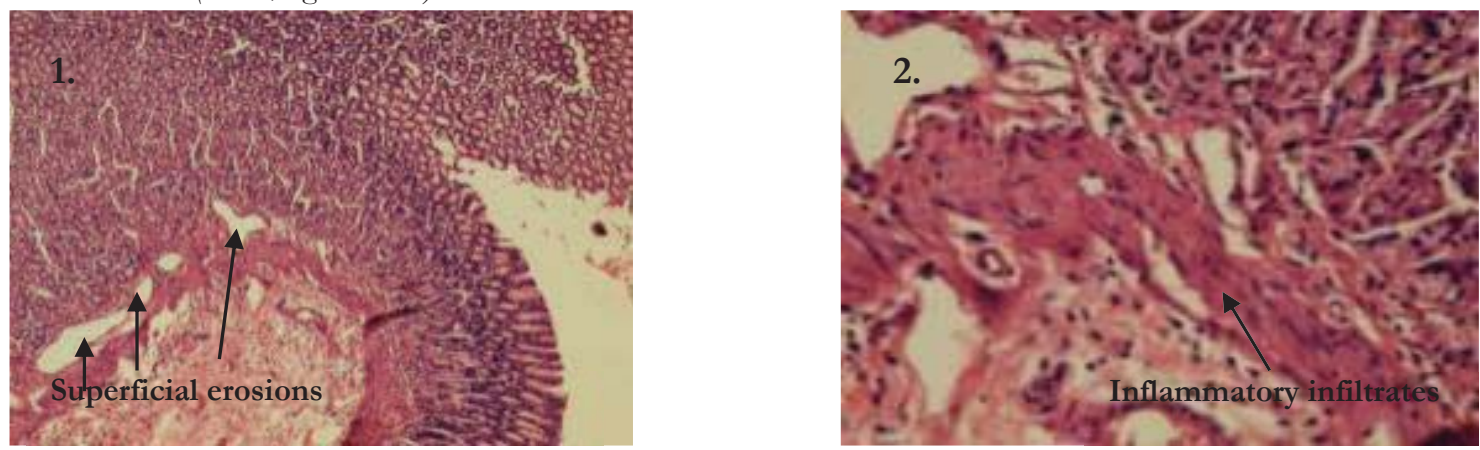

Figure $1 \& 2$. Photomicrograph showing surface erosions in gastric tissue with moderate inflammatory infiltrates in mucosal epithelium and very mild infiltrate in deeper coats
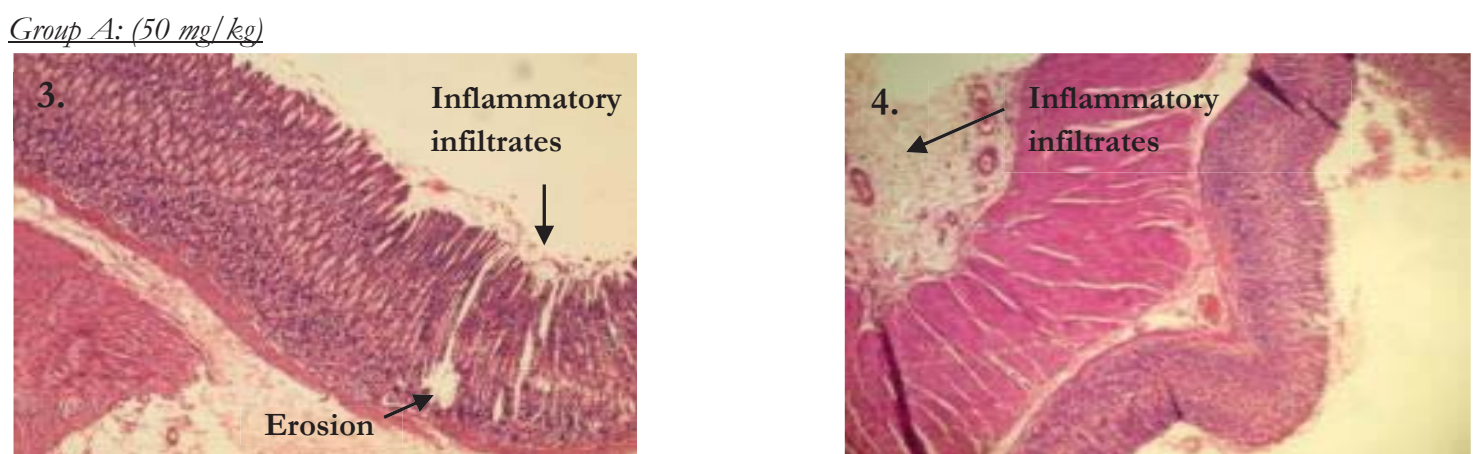

Figure $3 \& 4$. Photomicrograph of gastric tissue showing mild surface erosions
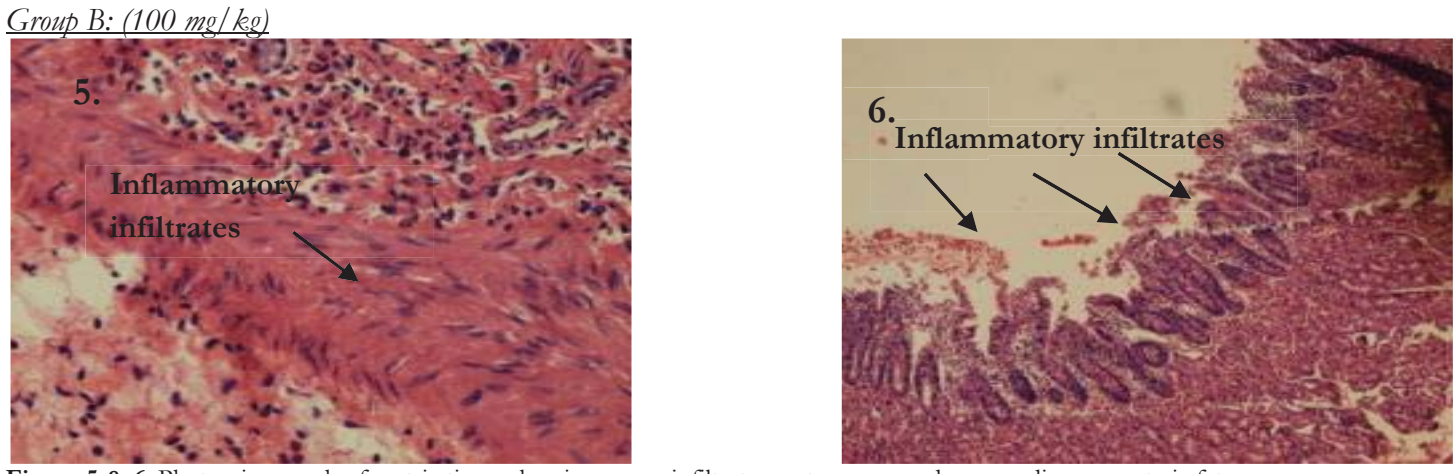

Figure $5 \&$ 6. Photomicrograph of gastric tissue showing sparse infiltrates up to serosa and surrounding mesenteric fat

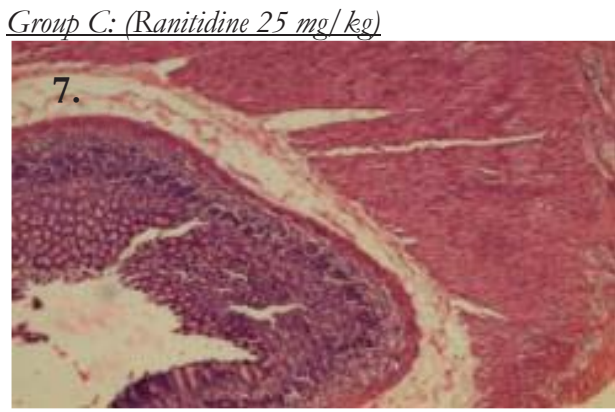

Figure 7. Photomicrograph of gastric tissue showing no ulcer, sparse infiltration 
STATISTICAL ANALYSIS

All values were reported as Mean \pm SD. The statistical significance of differences between groups was assessed by ANOVA, followed by student t-test. A probability value of ${ }^{*} \mathrm{p}<0.001$ was considered to be statistically significant.

\begin{tabular}{|c|c|c|c|c|c|}
\hline GROUPS & DOSE & $\begin{array}{c}\text { AVERAGE } \\
\text { NUMBER OF } \\
\text { ULCERS }\end{array}$ & $\begin{array}{c}\text { AVERAGE OF } \\
\text { SEVERITY SCORE }\end{array}$ & $\begin{array}{c}\text { ULCER INDEX } \\
\text { Mean } \pm \text { SD }\end{array}$ & PROTECTION \\
\hline $\begin{array}{c}\text { Control } \\
\text { (Vehicle } \% \text { gum acacia) }\end{array}$ & 7.5 & 18.33 & $* 18.33 \pm 1.67$ & 31.79 \\
\hline Group A & $50 \mathrm{mg} / \mathrm{kg} / \mathrm{day}$ & 1.16 & 1.33 & ${ }^{*} 1.33 \pm 0.33$ & 72.73 \\
\hline Group B & $100 \mathrm{mg} / \mathrm{kg} / \mathrm{day}$ & 0.5 & 0.5 & ${ }^{*} 0.50 \pm 0.34$ & 73.05 \\
\hline $\begin{array}{c}\text { Group C } \\
\text { (Ranitidine) }\end{array}$ & $25 \mathrm{mg} / \mathrm{kg} / \mathrm{day}$ & 0.33 & 0.33 & $* .33 \pm 0.21$ & \\
\hline
\end{tabular}

Table 1. Effect of Laghusoothshekhar on pyloric ligature induced gastric ulcers in albino rats

\section{CONCLUSION}

Laghusoothshekhar an ayurvedic formula for gastritis is a cost effective and holistic solution in the treatment of gastritis and peptic ulcers. The findings obtained proved the conventional indications of the drug and contributed to their antiulcer pharmacological validation leading to more credibility of its clinical applications.

\section{ACKNOWLEDGEMENT}

The authors thank the principal of Sion Ayurved Mahavidyalaya, Sion, Mumbai for providing fresh betel leaves and facility to prepare the formulation, also thank the Botany Department of SIES College of Arts, Science and Commerce, Sion, Mumbai for authenticating the betel leaves and ginger. We thank Dr. Jude Vaz HOD Pathology department of Holy Family Hospital, Bandra, Mumbai and Dr. Ketki Shah, Nanavati Hospital, Vile Parle, Mumbai for the reporting and photography of the histopathological slides of the gastric tissues provided.

\section{REFERENCES}

1. Tripathi, K.D. (1999) Essentials of Medical Pharmacology, drugs on peptic ulcers, $6^{\text {th }}$ ed., 628-642, Jaypee brothers, Medical publishers Pvt. Ltd., New Delhi.

2. N.L. Dashputre, Naikwade, N.S. (2011) Evaluation of antiulcer activity of methanolic extract of Abutilon indicum Linn leaves in experimental rats, Int. J. Pharma. Sci. Drug Res. 3(2), 97-100.

3. Mahady, G., Pendland, S., Yun, G., Lu, Z. and Stoia, A. (2003) Ginger (Zingiber officinale Roscoe) and the gingerols inhibit the growth of Cag A+ strains of Helicobacter pylori. Anticancer Res. 23, 3699-3702.

4. Siddaraju, M. N. and Dharmesh, S. M. (2007) Inhibition of gastric $\mathrm{H}^{+}, \mathrm{K}^{+}$-ATPase and Helicobacter pylori growth by phenolic antioxidants of Zingiber officinale. Mol. Nutr. Food Res. 51, 324-332.

5. Yamahara, J., Huang, Q., Li, Y., Xu, L. and Fujimura, H. (1990) Gastrointestinal motility enhancing effect of ginger and its active constituents. Chem Pharm Bull (Tokyo). 38(2), 430-431.

6. Yamahara, J., Rong, H., Iwamoto, M., Kobayashi, G., Matsuda, H. and Fujimura, H. (1989) Active components of ginger exhibiting antiserotinergic action. Phytotherapy. Res. 3, 70-71.

7. Huang, Q., Iwamoto, M., Aoki, S., Tanaka, N., Tajima, K., Yamahara, J., Takaishi, Y., Yoshida, M., Tomimatsu, T. and Tamai, Y. (1991) Anti-5-hydroxytryptamine 3 effect of galanolactone, diterpenoid isolated from ginger. Chem. Pharm. Bull. (Tokyo). 39, 397-399.

8. Ali, B., Blunden, G., Nemmar, A. (2008) Some phytochemical, pharmacological \& toxicological properties of ginger (Zingiber officinale Roscoe) a review of recent research, Food \& chemical toxicology, 46(2), 409-420.

9. Periyanayagam, K., Jagadeesan, M., Kavimani, S., Vetriselvan, T. (2012) Pharmacognostical \& phytophysiochemical profile of leaves of piper betel L.var Pachaikodi (piperaceae) - valuable assessment of its quality, Asian Pac J Trop Biomed. 2(2), 5065510 .

10. Jha, C. (2007) Ayurvediya ras shastra (A textbook of Rasashastra), Maharasa uprasa sadharan rasa-gairik, $2^{\text {nd }}$ edition, 249-250, Chaukmbha Surbharti Prakashan, Varanasi.

11. Gune, V.G.G. (2008) Ayurvediya Aushadhigundharmashastra, Vaidyagranth Bhandar Press, Pune, 447.

12. Bongo, S., Vijayakumar, S. (2012) Animal models in experimental gastric ulcer screening: a review, International journal of pharmacological screening, 2(2), 82-87.

13. Kulkarni, S.K., (1999) To study the antisecretory \& ulcer protective effect of cimetidine in pylorus ligated rats, Handbook of experimental pharmacology, $3^{\text {rd }}$ edition, Vallabh prakashan, Delhi, 148-150.

14. Paget, G.E., Berns, J.M., Lawranle, D.R., Bacharch, A.L. (1969) Evaluation of Drug Activities: Pharmacometrics, Vol. 1. New York: Academic Press. 
15. Shay, H., Komarov, S.A., Fels, S.E., Meraze, D., Gruenstein, M., Siplet, H.A. (1945) Simple method for the uniform production of gastric ulceration in rat, Gastroenterology, 5, 43-61.

16. Tammu, J., Venkataraman, K., Thallu, S. (2013), Antiulcer activity of methanolic extract of Physalis minima leaves, Int. J. PharmaTech Res. 337-340.

17. Nair, V., Arjuman, A., Gopalakrishna, H.N., Dorababu, P., Mirshad, P.V., Bhargavan, D., Chatterji, D. (2010) Evaluation of the antiulcer activity of NR-ANX-C (polyherbal formulation) in aspirin \& pyloric ligature induced gastric ulcers in albino rats, India J Med Res.132, 218-223

18. Jauhar, S.P. (2005) Modern's ABC of Chemistry, $d$ and f block elements, $9^{\text {th }}$ edition, 528-586, Modern publishers Pvt. Ltd, New Delhi.

\section{ABOUT THE STUDENT AUTHOR}

Nilofer Sayed is a final year undergraduate student in Pharmaceutical sciences (B. Pharm) and has done her Bachelors in Ayurved medicine \& surgery. Her interest lies in the discovery of new lead molecules and targets in the field of drug discovery and development.

\section{PRESS SUMMARY}

Laghusoothshekhar, an ayurvedic formulation comprising of dried ginger powder, purified yellow ochre and juice of betel leaves used by practitioners for gastritis and peptic ulcers but no documented evidence available. Hence, the study was carried out by administering the drug to albino rats and inducing ulcers by pyloric ligation. Animals were deprived of food and water for four hours thereafter sacrificed and the number of ulcers and their nature noted. The histological examinations of the gastric tissues were also performed. The effects of the formulation were as effective as ranitidine and the histological examinations supported the results. 